\section{A Young Man's View of the Aerospace Profession}

$\mathrm{H}$ AVING studied with interest the very thorough papers of Mr. H. M. Fincher and Mr. P. D. Ewins and the comments of Mr. C. G. B. Mitchell (Journal of the Royal Aeronautical Society, October 1966) I should like to make some comments which are the views of one who has graduated from Imperial College in Aeronautical Engineering and is now in industry - albeit for only fifteen months.

I feel that two extremes of education were put forward by the contributors and that a compromise solution might in this instance better serve the Aerospace profession. As Mr. Mitchell says the primary purpose of academic courses is to teach the student to orientate his own thinking and to learn how to ask the right questions. This the Universities tend to do, but possibly to the exclusion of considering the type of graduate that emerges. If the graduate is to go on to do research leading to advancement of theoretical knowledge then he has had the right training, but if he is to go into a design organisation, he must be given some indications as to how an aeroplane is conceived and how all the academic information he has been given can be used in fulfilling this conception. While one cannot and should not be "taught" design as a science, one should be told for instance why various components are required, what purpose or purposes they serve and how analysis can be developed to ensure that the integrity of the aeroplane is obtained. I think that this argument is relevant to all fields of Aeronautics, but particularly to Structural Design.

Thus it is essential to have design as part of a University curriculum, not as an examinable subject or as a subject for which there are "hard-and-fast" rules, but rather as a guide to the end result of one's training. For this reason I feel that Mr. Fincher goes too far in his suggested new course. The timetable proposed would in fact only be suitable after the fundamentals of the subject have been appreciated and could serve the requirements of design education (the seminar system that is) but would not necessarily help at all in the scientific aspects of engineering.

If one assumes that a sufficient number of the right men for industry have been trained we are now concerned with keeping them in Aeronautics, preferably British Aeronautics. I do not feel that the large numbers of civil servants at MoA or RAE really affects the morale of personnel in industry as suggested by $\mathrm{Mr}$. Fincher, in fact I doubt if the figures quoted are known by more than a handful of engineers. Neither is morale low now because of the decisions of the past 12 months, but because these 12 months came after the previous " $n$ " years, $i e$ it is a cumulative effect born over a long period of time. A large number of engineers are in Aeronautics because they "love aeroplanes" and it takes more than 2 or 3 cancellations to overcome this. While cancellations are undoubtedly an important factor the industry must be more introspective and management must be asked just what it is doing to encourage staff to stay within the industry. Could it be that the "love of aeroplanes" attitude is the root cause of the troubles in industry? The attitude seems at the moment to be an excuse for complacent management rather than being harnessed to provide the drive and motive power so essential.

Finally may I say that the Society is serving a very useful function by encouraging discussion of this kind, especially by the younger people in Aeronautics who share the love of the subject but have only just met the frustrations and feel that they would like to do something about them.

\section{A. J. Thirkettle, Graduate}

20th October 1966.

\section{Britain's Aerospace Industry}

It is now over 18 months since an anonymous Member gave his (or her) views on British Aviation in that unusual and penetrating article-"What Went Wrong? The Way Ahead"-which stirred us into a more acute awareness of what needed to be done about it. Please allow me to revive one or two aspects of it in these critical times.

The Plowden Committee was launched at that time and we all sat back hoping and expecting that the Plowden Report would put all to rights. Well, we had the disappointing Plowden Report almost 12 months ago and a great deal of talk about it since then. However, recently there has been some belated action to bring into effect some of the recommendations of the Plowden Report; for instance the merger of Rolls-Royce and Bristol Siddeley aero engine companies and the initiation of a merger of the British Aircraft Corporation and Hawker-Siddeley airframe groups. In the latter, the Government has pledged a stake commensurate to the Taxpayers' investment in the work of these companies. Also the Ministry of Aviation is about to be disbanded and its responsibilities split three ways between the Ministry of Technology, Ministry of Defence and the Board of Trade. (While the Industry has started to close and thereby strengthen its ranks, the Government's are opening; to what effect remains to be seen.)

But action to put new life-blood into what has now come to be called British Aerospace is more noticeable by its absence. No new British project, worthy of the name, since the deaths of TSR2, P1154 and HS681 has emerged. Indeed, the pre-Plowden and bold bread-winning venture, the Concorde, was very nearly abandoned by Britain before the Plowden Committee could investigate its worthiness. Unfortunately it would seem, Concorde's escape from an untimely death has led to the belief that this signifies the way ahead for the survival of Britain's aerospace industry. In consequence there has been a follow up of much misguided and unco-ordinated effort towards European Co-operation as recommended in the Plowden Report which is probably doing more harm than good to our much deflated industry by frittering away its assets in abortive Anglo-European adventures such as the Airbus. Instead we should have been concentrating our strength in recognition of the truth of one sentence in our anonymous friend's article 18 months ago which read, "Our economic security, of which the Services, the airlines and the manufacturing industries are all essential parts, is as vital in peace-time as is our defence security in war."

I think it was Earl Attlee who said, in an interview in June 1955, when defending Britain's need for nuclear arms, that until nations abandon their national sovereignty, we, as a nation, are bound to put our national interests above all others when our survival is threatened, and in the last resort use any weapon available to us to ensure our survival. This is a noteworthy acceptance of the facts of life as we have to live it and it is no less true today in the economic field as it is in aerospace. Consequently, it is irrational to suppose that the American monopoly in aerospace can be seriously challenged by so called European co-operation such as we have been attempting. It seems clear that until we have a "Federation of European States", with a unified government similar to that of the United States of America, and which is invested with supreme powers for the direction, control and with financial autonomy governing the nationally disposed indigenous industries, any agreements and arrangements between separate national organisations are at the mercy of purely national priorities.

Even if a supra-national European aerospace authority could be agreed upon whereby there was only one single supreme head of each and all of Anglo-European projects, 
there would be innumerable difficulties to overcome. Anyone who has served in NATO is familiar with them -customs, language, currencies, education, standards and methods are all quite different, not to mention the differences between the Metric and English standards of measurement. Therefore, those enthusiasts, however well intentioned on ideological grounds, who would prematurely try to integrate our aerospace industry into the hot-bed of European politics and industrial ambitions would do well to ponder long and hard on the commercial implications for us. We have sufficient evidence other than in NATO of the economic difficulties in our experience of the progress of the Concorde, the Airbus, ELDO and the VG projects in this context. They have cost us a great deal of money with very little return or much prospect for it so far which we could more profitably have spent on our aerospace industry at home. Moreover, apart from the apparent waste of time and money on these co-operative ventures, our technological competitiveness and bargaining power by which to obtain entry into the Common Market in Europe is being undermined by the fact that the EEC is acquiring our technology on easy terms while it is at the same time building up its tariff wall against us! Could we be more stupid? What is the alternative?

Our aerospace industry, if it is to survive, needs a very broad base for research and development, a great deal of financial investment, and a very large and sophisticated market for its products. Our home market together with that of the Commonwealth and EFTA are not enough. The whole market in Europe is essential for our exploitation and advancement in advanced technology of which aerospace plays a leading part. We cannot sell enough computers and aero engines to under-developed and under-populated parts of our Commonwealth under Imperial preferences to keep us alive, let alone enable us to build up strength to compete in the American markets, and against American competition in the world's open markets. That is why it is supremely important that we join the EEC and enter the Common Market, even at the cost of foregoing benefits of Imperial preferences, such as cheaper food and raw materials. Otherwise we might as well stay as we are, trade our Scotch whisky for French champagne, or our poprecords for American tobacco, while our aerospace languishes and withers away for lack of orders. Do we want to reduce our nationhood to that level? I think not.

If we want to produce aerospace products worthy of our heritage, our energies should now be directed towards getting our aerospace industry organised into its strongest position so that when we come to bargain with the EEC for entry into the Common Market, we can do so from a position of strength and on a quid pro quo basis in conformity with the provisions of the original Treaty of Rome. Europe needs our technology just as much as we need the European market to sustain it. We have much to offer the EEC and we have formidable assets, although we have some repairable weaknesses, if we can recognise them for what they are worth. We have a wealth of scientific talent; a large public investment in our R \& D establishments; we have technicians, tools, factories, fuel and power to hand; we have experience and skills, native inventive genius and flexibility of mind, organisations and world-wide communications; and we have advanced techniques in aeroengines, electronics, instruments and processes; we have first rate foremen and a new generation of young and ambitious technocrats impatient to get into new frontiers of technology, or seek them abroad. But they all badly need leadership; dynamic leadership and management at the highest levels in our industry; men bred in an aerospace environment. (We suffer from the lack of an "Ecole de
Polytechnique or an Academy of Science and Technology".) We are thin on the ground with capable chief production engineers and works managers who are trained in the disciplines of controlling time schedules and weight and cost limitations. We need designers who are cost conscious and weight conscious to meet commercial performance limitations, as well as operational limitations. Above all we need a lot of investment capital and an assured profitable return for it.

We need a focal point from which to point "the way ahead" that was specified so admirably in the Member's article. Contrary to Peter Masefield's proposal for an Aerospace Planning Authority, I would advocate an "Aerospace Advisory Bureau", located in the Ministry of Technology, now that the Ministry of Aviation is being abandoned, to which industry, the Service departments, the airlines, research and development establishments, and the press could turn for advice, guidance, direction and information, and reciprocally, from where the Ministry of Technology could guide the efforts of the aerospace industry for the national good. (This Bureau could undertake feasibility studies and compile statistics and similar tasks for the Minister and responsible authorities, but it would have no authority or responsibility per se. Real authority can only be invested in those who have the responsibility for actions and thereby are accountable for the consequences. All would agree that this axiom must be inviolable for the Ministry of Defence: it follows that it must hold good for all other executive authorities.)

To achieve our aims in aerospace we must discard old methods and sentiments that hinder us. For example, we should be prepared to employ an agency, whether American or European, to work for us if it fills a gap in our industry and in order to achieve the end product. Alternatively, we should be willing, and anxious, to undertake contract work to keep our industry going from any international source, and we should encourage the free exchange of personnel abroad in order to help to broaden our expertise in the industry and thereby offset complacency. We need to back all this with a wider and more confident appeal to the investing public. (The constant cry of lack of capital appears to be contradicted by the tremendous rushes of private capital to subscription lists on the Stock Exchange; for instance the $£ 2000$ million that was revealed when ICI called for a loan of $£ 60$ million recently!) If the industry can offer the investing public sound and profitable projects, backed up by merchant bankers who can be convinced by the merits of commercially and technically sound prospectuses and specifications, the future of the industry is assured, since it is unquestionably apparent that financially, it must pay for itself.

There is much urgent work claiming the attention of our aerospace industry. Among the many projects awaiting initiating action are: a world-beating Airbus (a shorthaul Jumbo Jet); a VTO front-line GD fighter to follow the P1127; a VTO transport to follow the Airbus; a VG long-range strike aircraft to follow the GD F-111; a worldbeating light twin private and business aircraft; a blindlanding aircraft/airport package; a space communications satellite (military and civil); a sub-orbital ram and rocket jet transport to follow the SST's toward the end of the century. All these, in my view, are within Britain's capabilities if we choose to embark on them from our own resources. We can keep our feet on the ground while the USA and the USSR expend their surplus energies in trying to reach the Moon and exploring it. Our work could be infinitely more rewarding for our technological health and national economy. So what are we waiting for?

24th November 1966.

E. A. Harrop, Fellow 